\title{
RANTAI PASOK KOMODITAS KACANG TANAH DI KABUPATEN MUNA
}

\author{
Abdul Rahman ${ }^{1)}$, Usman Rianse $^{2)}$, Sitti Aida Adha Taridala ${ }^{2)}$ \\ ${ }^{1)}$ Pascasarjana Universitas Halu Oleo \\ ${ }^{1)}$ Email: abdulrahmanitp@gmail.com \\ ${ }^{2)}$ Tenaga Pengajar Pascasarjana Universitas Halu Oleo
}

Naskah diterima: 11 April 2019

Naskah direvisi: 19 April 2019

Disetujui diterbitkan: 28 April 2019

\begin{abstract}
This research aims to analyze (1) supply chain path, and (2) the performance of a supply chain commodity peanut Muna Regency. Sampling method used in this research was simple random sampling and snowball sampling. Supply chain path analyzed in qualitative descriptive. Supply chain performance is analyzed with a model approach to Supply Chain Operations Reference (SCOR). The results showed that members of the supply chain consists of peanut farmers, village collector (PPD), Sub-district collector (PPK) and inter-insular traders (PAP). There are three pathways of a supply chain that is a path I: farmer $\rightarrow$ PPD $\rightarrow$ PAP; path II: farmer $\rightarrow$ PPK $\rightarrow$ PAP; and path III: farmer $\rightarrow$ PAP. Supply chain performance attributes based on shipping and order fulfillment cycle, farmers are in the position and traders are at a good position.
\end{abstract}

Keywords: peanuts, supply chains, traders, SCOR

Intisari: Studi ini bertujuan untuk menganalisis (1) jalur rantai pasok, dan (2) kinerja rantai pasok komoditas kacang tanah di Kabupaten Muna. Metode pengambilan sampel yang digunakan dalam studi ini adalah simple random sampling dan snowball sampling. Jalur rantai pasok dianalisis secara deskriptif kualitatif. Kinerja rantai pasok dianalisis dengan pendekatan model Supply Chain Operations Reference (SCOR). Hasil studi menunjukkan bahwa anggota rantai pasok kacang tanah terdiri dari petani, Pedagang Pengumpul Desa (PPD), Pedagang Pengumpul Kecamatan (PPK) dan Pedagang Antar Pulau (PAP). Terdapat tiga jalur rantai pasok, yaitu jalur I: petani $\rightarrow$ PPD $\rightarrow$ PAP; Jalur II: petani $\rightarrow$ PPK $\rightarrow$ PAP; dan Jalur III: petani $\rightarrow$ PAP. Berdasarkan atribut kinerja rantai pasok pada pengiriman dan siklus pemenuhan pesanan, petani berada pada posisi kurang baik dan pedagang berada pada posisi baik.

Kata kunci : kacang tanah, rantai pasok, pedagang, SCOR

\section{PENDAHULUAN}

Kacang tanah merupakan salah satu tanaman legum yang sudah dikenal dan dibudidayakan di Indonesia. Kacang tanah mempunyai nilai ekonomi tinggi karena kandungan gizinya terutama protein dan lemak yang tinggi, namun perkembangan luas panen dan produksi selama kurun waktu 5 tahun terakhir (2008-2012) terus mengalami penurunan. Luas panen turun rata-rata 2,28 persen dan produksi turun rata-rata 1,02 persen per tahun. Di lain pihak, kebutuhan kacang tanah yaitu rata-rata 900.000 ton/tahun, produksi 771.022 ton/tahun dengan volume impor 163.745 ton/tahun (Direktorat Budidaya Aneka Kacang dan Umbi, 2012).

Berlakunya Masyarakat Ekonomi Asean bisa menjadi peluang sekaligus ancaman bagi pertanian di Indonesia. Kerja sama pertanian tanaman pangan menghasilkan skema kerjasama ASEAN antara lain Integrated Food Security dan Food Security Information System yang bertujuan untuk menciptakan pasar yang kondusif serta berfokus pada pengumpulan, analisis, diseminasi dan informasi 
pertanian (Dirjen Kerjasama ASEAN, 2015 dalam Hidayati, 2017). Namun demikian, hal tersebut harus diimbangi dengan kemampuan petani dalam mengembangkan bargaining power-nya dalam jaringan rantai pasok.

Penerapan manajemen rantai pasok yang tidak lancar dan efisien menyebabkan berbagai permasalahan di sepanjang rantai pasokan. Mulai dari tingginya biaya operasional bagi pelaku usaha, tidak berpihaknya pelaku usaha pada petani dan befluktuasinya harga komoditi. Penerapan konsep manajemen rantai pasok yang baik, maka diharapkan dapat meningkatkan daya saing yang tinggi bagi semua pihak didalam rantai pasokan (Marimin dan Maghfiroh, 2010).

Provinsi Sulawesi Tenggara merupakan salah satu daerah penghasil kacang tanah. Komoditas ini mempunyai peranan penting dalam perekonomian yang diarahkan untuk meningkatkan hasil produksi dan pendapatan petani kacang tanah. Kabupaten Muna merupakan daerah penghasil kacang tanah tertinggi di Provinsi Sulawesi Tenggara dengan luas panen 1.055 hektar dan produksi 4.110 ton (BPS, 2017). Oleh karena itu komoditas ini memiliki potensi untuk dikembangkan lebih jauh sebagai salah satu komoditas unggulan. Berdasarkan data dari Pusat Data dan Sistim Informasi Pertanian (2016) dan BPS tahun 2017, dapat disampaikan bahwa sering terjadi gejolak harga komoditas kacang tanah antar waktu karena adanya kesenjangan antara pasokan dan permintaan. Persoalan tersebut dapat diatasi melalui pengelolaan sistem logistik yang efektif dan efisien. Untuk memperoleh sistem pengelolaan tersebut, maka digunakan konsep Supply Chain Management. Hal ini karena rantai pasok yang efektif dan efisien dapat mengintegrasikan sumber daya yang ada dan mengurangi biaya logistik (Fan et al., 2013 dalam Septiana, 2017). Sama halnya dengan komoditas pertanian lainnya, pengelolaan rantai pasok komoditas kacang tanah cukup kompleks. Sistem logistik kacang tanah memiliki karakteristik tertentu karena dipengaruhi oleh sistem produksi, bulky, perishable dan perubahan yang terus menerus pada kualitasnya sedangkan permintaan terhadap kacang tanah terjadi sepanjang waktu. Permintaan konsumen akan kacang tanah harus senantiasa terpenuhi agar keuntungan pelaku rantai pasok dapat tercapai. Oleh karena itu, upaya peningkatan kinerja rantai pasok kacang tanah menjadi sangat diperlukan.

\section{METODE STUDI}

Studi ini dilaksanakan pada bulan September 2018 sampai Mei 2019. Lokasi studi dari tingkat Kabupaten dipilih dua Kecamatan secara purposive, yaitu Kecamatan Bone dan Kontunaga, dengan pertimbangan bahwa daerah tersebut merupakan penghasil tertinggi komoditas kacang tanah berdasarkan data BPS Kabupaten Muna tahun 2017.

Populasi dalam studi ini yaitu petani dan pedagang. Populasi petani yakni semua petani kacang tanah di Kecamatan Bone dan Kecamatan Kontunaga yang berjumlah 740 orang. Penentuan sampel petani dilakukan secara simple random sampling. Pengambilan sampel pedagang dilakukan dengan snowball sampling. Data yang dikumpulkan dalam studi ini meliputi data primer dan data sekunder. Analisis data dilakukan secara deskriptif dan kuantitatif.

\section{HASIL DAN PEMBAHASAN}

\section{Anggota Pasok Kacang Tanah}

Anggota rantai pasok adalah semua pihak yang berhubungan secara langsung ataupun tidak langsung dalam kegiatan produksi suatu perusahaan atau organisasi mulai dari hulu sampai hilir. Pemasok bahan baku merupakan pihak di bagian hulu dan konsumen akhir berada pada bagian hilir. Menurut Indrajid dan Djokopranoto (2002), anggota rantai pasok terdiri atas pemasok, perusahaan (pengolah), distributor, pengecer dan konsumen. Pada studi ini identifikasi rantai pasok dimulai dari petani kacang tanah (hulu) sampai pedagang antar pulau. 
a. Petani

Petani kacang tanah sebagai mata rantai di bagian hulu merupakan pemasok utama di dalam rantai pasokan. Hingga saat ini komoditas kacang tanah di Indonesia sebagian masih bergantung pada impor untuk memenuhi permintaan pasar. Pembudidayaan kacang tanah masih menggunakan sistim pengelolaan tradisional yang hasilnya belum mampu memenuhi kebutuhan konsumen.

Berdasarkan hasil studi, dapat disampaikan bahwa luas lahan yang diusahakan petani kacang tanah berkisar antara 0,5-1 Ha. Kacang tanah yang dihasilkan oleh petani berjumlah sekitar 70-80 persen dijual, dan sisanya dialokasikan untuk benih dan konsumsi petani dan keluarganya. Petani umumnya menjual hasil panennya kepada pedagang pengumpul. Sebagian besar petani menjual kepada pedagang pengumpul disebabkan adanya 1) asas saling percaya dan telah berlangsung sejak lama, 2) cara yang praktis dan cepat dalam mendapatkan uang. Hasil studi menunjukkan bahwa sebesar 45 persen petani kacang tanah langsung menjual hasil panennya ke Pedagang Pengumpul Desa. Hal tersebut dilakukan untuk cepat mendapatkan uang dan mengurangi risiko susut atau termakan oleh tikus dan hama lainnya.

\section{b. Pedagang Pengumpul Desa (PPD)}

PPD merupakan pedagang yang melakukan aktivitas jual belinya dalam lingkup desa dimana pedagang berdomisili. Berdasarkan data studi, diketahui bahwa Pedagang Pengumpul Desa berjumlah 5 orang. PPD melakukan pembelian kacang tanah gelondongan maupun pipilan dari para petani kacang tanah di desanya. Selanjutnya, PPD melakukan proses pengolahan kacang tanah gelondongan menjadi kacang tanah pipilan kering. Hasil pengolahan kacang tanah pipilan kering kemudian dijual pada Pedagang Antar Pulau dan pembeli lainnya. PPD juga bertindak sebagai Pedagang pengecer yang menjual langsung kepada konsumen di Pasar lokal yang ada di desa terdekat tempat tinggal mereka.

\section{c. Pedagang Pengumpul Kecamatan/Kabupaten (PPK)}

Berdasarkan jumlah modal yang dimiliki untuk membeli kacang tanah, PPK dibagi menjadi dua kategori, yaitu PPK yang menggunakan dana pinjaman dari perbankan dan PPK yang tidak menggunakan pinjaman atau hanya menggunakan dana pribadi. PPK yang tidak menggunakan pinjaman atau hanya menggunakan dana pribadi berjumlah 3 orang, sedangkan PPK yang menggunakan dana pinjaman dari perbankan berjumlah 2 orang. PPK melakukan pembelian kacang tanah dari petani, sehingga aktivitas pembelian PPK hampir sama dengan aktivitas pembelian PPD pada saat melakukan pembelian langsung ke petani dan sebagian lainnya melakukan pembelian di Pasar Kecamatan. Selanjutnya, PPK langsung menjual pada Pedagang Antar Pulau dan pembeli lainnya. Seperti PPD, PPK juga bertindak sebagai Pedagang pengecer yang menjual langsung kepada konsumen di Pasar lokal yang ada di desa atau desa terdekat mereka tinggal.

\section{d. Pedagang Antar Pulau (PAP)}

Pedagang antar pulau merupakan pedagang yang melakukan kegiatan pembelian kacang tanah, baik dari PPD, PPK maupun dari petani. Pelaku PAP berjumah 4 orang atau kurang dari jumlah Pedagang Pengumpul Desa dan berlokasi jauh dari produsen atau petani kacang tanah. Pedagang PAP memiliki tempat penjualan yang berlokasi di Kota Bau-bau dan Kendari. Pedagang antar pulau di Kota Bau-bau berjumlah 3 orang dan di Kota Kendari sebanyak 1 orang. Kacang tanah yang dibeli dari petani, pedagang pengumpul desa, dan Pedagang Pengumpul Kecamatan dalam bentuk kacang pipilan kering.

\section{e. Konsumen}

Berdasarkan data studi, dapat disampaikan bahwa konsumen kacang tanah terdiri dari rumah tangga, pabrik roti dan rumah makan coto. Umumnya dalam pemenuhan kebutuhan akan kacang tanah, konsumen membeli di pasar dan tidak pernah membeli langsung di petani, hal ini terjadi karena harga pada petani hampir sama dengan harga di pasar. Begitupun dengan konsumen di luar Kabupaten Muna, seperti Bau-bau dan Kendari. Namun demikian konsumen pada dua daerah tersebut mempunyai preferensi yang berbeda terhadap jenis kacang tanah, dimana konsumen di Kota Kendari mempunyai 
kecenderungan menyukai kacang tanah berwarna putih dan konsumen di Kota Bau-bau mempunyai kecenderungan menyukai kacang tanah berwarna merah.

\section{Jalur Rantai Pasok}

Jalur rantai pasok adalah jalur yang terbentuk dari kegiatan bisnis yang dimulai dari petani kacang tanah sampai pada konsumen. Jalur rantai pasok yang terbentuk dapat dikelompokkan menjadi tiga jalur yang kemudian disebut sebagai jalur I, jalur II dan jalur III. Anggota dari masing-masing jalur terdiri dari petani, PPD, PPK dan PAP. Jalur I dimulai dari Petani $\rightarrow$ PPD $\rightarrow$ PPK $\rightarrow$ PAP. Jalur II dimulai dari Petani $\rightarrow$ PPK $\rightarrow$ PAP. Jalur III dimulai dari Petani $\rightarrow$ PAP. Sejalan dengan penelitian Taridalla et al., 2013 bahwa masing-masing anggota rantai pasokan saling tergantung dan petani selaku produsen tidak dapat menjual langsung produknya ke konsumen akhir. Kelompok petani yang berada pada jalur I dan II merupakan kelompok petani yang hasil produksinya di bawah $100 \mathrm{Kg}$ dan petani yang menjual kacang tanah dalam bentuk gelondongan. sehingga mereka langsung menjual kacang tanah yang mereka peroleh agar dapat segera digunakan hasilnya untuk mencukupi kebutuhan seharihari.

Kelompok petani di jalur III merupakan petani yang umumnya lebih berpengalaman, produksinya di atas $100 \mathrm{Kg}$ dan menjual kacang tanah dalam bentuk pipilan. Pengalaman yang mereka miliki membuat mereka mampu mendapatkan hasil yang lebih banyak. Pada kondisi demikian, kacang tanah akan lebih menguntungkan jika diolah sendiri dan dijual dalam bentuk pipilan dibandingkan dijual dalam bentuk gelondongan segar atau kering.

\section{Kinerja Rantai Pasok dengan pendekatan SCOR}

Pengukuran kinerja rantai pasok dilakukan berdasarkan matrik SCOR yang terdiri dari atribut reliability, fleksibility, responsiveness, aset dan cost. Pengukuran kinerja dengan metode ini dapat menjelaskan secara rinci tentang manajemen rantai pasokan kacang tanah di Kabupaten Muna. Informasi mengenai nilai rata-rata atribut kinerja rantai pasok disajikan pada Tabel 1.

Tabel 1. Nilai Rata-Rata Atribut Kinerja Rantai Pasok Kacang Tanah

\begin{tabular}{|c|c|c|c|c|r|r|}
\hline \multirow{2}{*}{$\begin{array}{c}\text { Atribut } \\
\text { SCM }\end{array}$} & Indikator Kinerja & \multicolumn{2}{|c|}{ Benchmarking (Pembanding) } & \multicolumn{2}{|c|}{ Nilai } \\
\cline { 3 - 7 } & & $\begin{array}{c}\text { Parity } \\
\text { Cukup }\end{array}$ & $\begin{array}{c}\text { Advantage } \\
\text { Baik }\end{array}$ & $\begin{array}{c}\text { Superior } \\
\text { Terbaik }\end{array}$ & Petani & Pedagang \\
\hline \multirow{2}{*}{ Reliability } & Kinerja Pengiriman (\%) & $85.00-89.00$ & $90.00-94.00$ & $\geq 95.00$ & 67 & 100 \\
\cline { 2 - 7 } & Kesesuaian Standar (\%) & $80.00-84.02$ & $85.00-89.00$ & $\geq 90.00$ & 98,1 & 99,7 \\
\hline Flexibility & Fleksibility (hari) & $42.00-27.00$ & $26.00-11.00$ & $\leq 10.00$ & & 7 \\
\hline Respon & $\begin{array}{c}\text { Lead time pemenuhan } \\
\text { pesanan (hari) }\end{array}$ & $7.00-6.00$ & $5.00-4.00$ & $\leq 3.00$ & 7 & 3 \\
\hline \multirow{2}{*}{ Sivenes } & $\begin{array}{c}\text { Siklus pemenuhan pesanan } \\
\text { (hari) }\end{array}$ & $8.00-7.00$ & $6.00-5.00$ & $\leq 4.00$ & 9 & 5 \\
\hline \multirow{2}{*}{ Aset } & $\begin{array}{c}\text { Cash to cash cycle time } \\
\text { (hari) }\end{array}$ & $45.00-34.00$ & $33.00-21.00$ & $\leq 20.00$ & 1 & 7 \\
\cline { 2 - 7 } Cost & Persediaan (hari) & $27.00-14.00$ & $13.00-0.01$ &.$=0.00$ & 11,4 & 71,4 \\
\hline
\end{tabular}

\section{a. Kinerja Pengiriman}

Kinerja pengiriman merupakan atribut yang menunjukkan kehandalan petani dan pedagang kacang tanah dalam memenuhi permintaan konsumen. Tabel 1 menunjukkan bahwa nilai rata-rata kinerja pengiriman petani sebesar $67 \%$ dan pedagang mencapai $99 \%$, artinya petani belum menempati posisi kerja baik sedangkan pedagang sudah menempati posisi kinerja terbaik dalam menjalankan aktivitas rantai pasok. Ketika sudah mencapai $100 \%$ artinya pencapaian kinerja pengiriman sudah 
berada pada posisi kesempurnaan (Yolandika et al., 2016). Dengan demikian dapat dikatakan bahwa pedagang sudah mampu memenuhi permintaan konsumen dengan tepat waktu. Artinya bahwa kacang tanah selalu ada di pasar, dan konsumen tidak akan khawatir terhadap kurangnya kacang tanah.

\section{b. Kesesuaian dengan Standar}

Kepuasan kosumen merupakan tujuan akhir dari sebuah rantai pasok kacang tanah. Salah satu indikatornya adalah kesesuaian produk dengan standar yang diinginkan konsumen. Tabel 1 menunjukkan bahwa nilai rata-rata kesesuaian standar pada petani sebesar $98 \%$ dan pedagang $99 \%$ atau berada di posisi baik. Artinya kemampuan petani dan pedagang dalam menghasilkan dan atau memasarkan kacang tanah sudah baik, namun perlu ditingkatkan kemampuan petani yakni melalui pelatihan aktivitas pasca panen. Aktivitas ini bisa mengurangi jumlah kerusakan kacang tanah setelah pasca panen.

Hasil studi menunjukkan bahwa setelah panen, petani menyimpan atau membiarkan hasil panennya yang berupa kacang tanah dengan pohonnya di atas tanah sekitar 20 hari atau sampai selesai panen. Hal ini bisa mengakibatnya jumlah produksi kacang tanah berkurang karena dimakan tikus dan binatang buas lainnya serta dapat menurunkan kualitas kacang tanah. Menurut Sari (2015), semakin dekat nilai rata-rata kesesuaian standar menuju angka $100 \%$, maka semakin baik kinerja rantai pasoknya.

\section{c. Fleksibilitas}

Setiap pedagang dan produsen membutuhkan waktu untuk menanggapi atau merespon pesanan yang tidak terduga. Tabel 1 menyajikan nilai fleksibilitas rantai pasok kacang tanah pada pedagang adalah 7 hari. Padahal ketika waktu siklus pemenuhan pesanan mencapai 10 hari artinya sudah mencapai posisi superior (Bolstroff dan Rosenbaum, 2011). Maka dapat dikatakan bahwa pedagang kacang tanah mampu memenuhi perubahan pesanan tidak terduga dengan sangat baik yaitu dalam kurun waktu kurang dari 7 hari. Kemampuan pedagang kacang tanah tersebut tentu membuat pihak pelanggan merasa puas dalam menjalin kerjasama.

\section{d. Lead Time Pemenuhan Pesanan}

Perhitungan nilai waktu tunggu yang digunakan petani kacang untuk memenuhi pesanan retail diketahui dari nilai rata-rata waktu tunggu yang digunakan petani kacang untuk memenuhi permintaan retail dalam satu pengiriman pasokan. Tabel 1 menunjukkan bahwa nilai lead time pemenuhan pesanan petani kacang tanah adalah 7 hari, artinya kinerja rantai pasok dalam lead time pemenuhan pesanan sudah mencapai posisi baik. Keberadaan pemasok menempati posisi yang sangat penting, sebab keterlambatan pasokan dapat merusak tatanan operasional perusahaan. Oleh karena itu, perusahaan harus mampu mengelola dan menjaga keharmonisan kerjasama dengan para pemasoknya (Manu et al., 2009).

\section{e. Siklus Pemenuhan Pesanan}

Setiap satu kali periode pemenuhan pesanan menunjukkan lamanya waktu yang diperlukan perusahaan untuk memenuhi pesanan tersebut. Semakin rendah nilai siklus pemesanannya, semakin baik capaian kinerja rantai pasoknya (Yolandika et al., 2016). Tabel 1 menunjukkan besarnya nilai untuk siklus pemenuhan pesanan kacang dari petani yaitu 9 hari dan pedagang adalah 5 hari, siklus pemenuhan pesanan pada petani berada pada posisi kurang baik dan pedagang berada pada posisi baik. Posisi petani kurang baik pada siklus pemenuhan pesanan ini, artinya petani belum mampu menyediakan kacang tanah secara terus menerus. Namun pedagang dapat menyediakan kacang tanah secara terus menerus.

\section{f. Cash to Cash Cycle Time}

Atribut kinerja ini berupa matrik yang menghitung kecepatan rantai pasok mengubah persediaan menjadi uang. Semakin cepat waktu yang digunakan untuk mengubah persediaan, semakin bagus pula pencapaian kinerja rantai pasoknya (Pujawan dan Mahendrawathi, 2017). Berdasarkan Tabel 1 nilai 
cash to cash cycle time petani 1 hari dan pedagang kacang tanah adalah 7 hari. Artinya perputaran uang tunai pada petani maupun pedagang kacang tanah sudah mencapai posisi sangat baik karena masih kurang dari 20 hari.

\section{g. Persediaan Harian}

Persediaan harian merupakan lamanya hari yang cukup dengan persediaan yang ada jika tidak terjadi keberlanjutan pasokan kacang tanah. Berdasarkan Tabel 1 dapat disampaikan bahwa nilai persediaan harian pada petani kacang tanah adalah $11,4 \mathrm{Kg}$ /hari sedangkan persediaan harian pada pedagang adalah $71,4 \mathrm{Kg} /$ hari karena pedagang kacang tanah ada perencanaan untuk melakukan persediaan, dan setiap minggu harus ada pasokan kacang tanah dari petani.

\section{h. Total Supply Chain Cost}

Total supply chain cost yaitu banyaknya biaya yang dikeluarkan perusahaan untuk aktivitas mulai dari pasca panen hingga kacang tanah sampai ke tangan retail. Tabel 1 menunjukkan bahwa petani kacang tanah mempunyai nilai capaian total biaya rantai pasok sebesar 4,1\% dan pedagang sebesar 4,4 $\%$. Maka dapat dikatakan bahwa kinerja rantai pasok petani kacang tanah dari sisi manajemen biaya masih belum baik. Perlu adanya upaya-upaya perbaikan untuk meminimalisasi biaya rantai pasok yang berpotensi menyebabkan pemborosan dana seperti biaya transportasi.

\section{KESIMPULAN DAN SARAN}

Kesimpulan:

1. Jalur rantai pasok kacang tanah terdiri atas tiga jalur. Jalur I: petani $\rightarrow$ PPD $\rightarrow$ PAP; Jalur II: petani $\rightarrow$ PPK $\rightarrow$ PAP; dan Jalur III: petani $\rightarrow$ PAP.

2. Atribut kinerja rantai pasok pada pengiriman dan siklus pemenuhan pesanan, petani berada pada posisi kurang baik dan pedagang berada pada posisi baik. Nilai total biaya rantai pasok kinerja masih diatas $3 \%$, sehingga minimalisasi biaya transportasi dan kemasan perlu untuk ditingkatkan.

Saran:

1. Perlunya pengembangan kacang tanah yang telah disortasi.

2. Perlunya kerjasama antar lembaga pemasaran.

\section{DAFTAR PUSTAKA}

BPS, 2017. Kabupaten Muna dalam Angka. Badan Pusat Statistik Kabupaten Muna, Raha.

Bolstorff, P., Rosenbaum, R., 2011. Supply Chain Excellence: A Handbook for Dramatic Improvement using the SCOR Model. AMACOM. New York

Direktorat Budidaya Aneka Kacang dan Umbi, 2012. Pedoman Teknis Pengelolaan Kacang Tanah, Kacang Hijau, dan Aneka Kacang. Prosiding. Direktorat Jendral Tanaman Pangan Kementerian Pertanian, Jakarta.

Hidayati, D. R., 2017. Rantai Pasok (Supply Chain) Pemasaran Komoditas Kacang Tanah di Kabupaten Bangkalan. Jurnal Pamator. Vol. 10 (1): 11-14.

Manu, Ila, Sahin, and Funda. 2011. A model of Supply Chain and Supply Chain Decision making Complexity. International Journal of Physical Distribution and Logistics Management. Vol. 41(5): 511-549.

Marimin dan Maghfiroh, N. 2010. Aplikasi Teknik Pengambilan Keputusan dalam Rantai Pasok. IPB Press. Bogor.

Nuryati, L. dkk. 2016. Outlook Komoditas Pertanian Tanaman Pangan Kacang Tanah. Prosiding. Pusat Data dan Sistem Informasi Pertanian. Kementerian Pertanian.

Pujawan dan Mahendrawathy, 2010. Supply Chain Management. Edisi Kedua. Guna Widya. Surabaya. 
Sari, P.N. 2015. Pengaruh Relationship Marketing terhadap Kinerja Rantai Pasok Beras Organik Bersertifikat di Kabupaten Bandung Melalui Integrasi. Tesis. Institut Pertanian Bogor.

Septiana, L.R., Machfud dan Yuliasih, I., 2017. Peningkatan Kinerja Rantai Pasok Bawang Merah (Studi Kasus: Kabupaten Brebes). Jurnal Teknologi Industri Pertanian.Vol. 27 (2): 125-140.

Taridala, S.A.A, Jusoff, K., Zani, M., Abdullah, W.G., Suriana and Merdekawati, I. 2013. Supply Chain in Sago Agribusiness. World Applied Sciences Journal. Vol. 26: 7-12.

Yolandika, C. 2016. Analisis Supply Chain Management Brokoli CV. Yan's Fruit and Vegetable di Kabupaten Bandung Barat. Tesis. Program Magister Agribisnis. IPB. Bogor. 